\title{
Superficial hardening improvement of nano and micro composite AI TiC
}

AbDeRRAouf GHERISSI - Department of Mechanical Engineering, Faculty of Engineering, University of Tabuk, KSA - Saudi Arabia - gherissi.abderraouf@gmail.com

MALIK ALI - Department of Mechanical Engineering, Faculty of Engineering, University of Tabuk, KSA - Saudi Arabia - malikali77@yahoo.com

Érkezett: 2019. 11. 13. " Received: 13. 11. 2019. " https://doi.org/10.14382/epitoanyag-jsbcm.2020.5

\begin{abstract}
The present investigation aims to study the improvement of the composite surface hardness by air abrasive jet polishing (AJP) of $\mathrm{SiO}_{2}$ particles. The experiments were conducted by synthesizing Al-TiC composites through melting the aluminum at $850^{\circ} \mathrm{C}$ and added TiC gradually for 10 minutes to the liquefied aluminum with different sizes and ratios (300-500 nm and 100-200 $\mu \mathrm{m})$ and $(5,10,15,20$ and 25 wt.\%) respectively of TiC. The molten Al-TiC was poured to a previously prepared sand mould. The hardness improvement for pure Aluminum, Al- micro-TiC and Al- nanoTiC composites were $7 \%, 11 \%$, and $15 \%$ respectively. The obtained results demonstrate the importance of superficial hardening of composites Al-TiC by impact of the $\mathrm{SiO}_{2}$ air jet and show that the surface hardness improvement is greatest for the nanocomposites compared with microcomposite and pure matrix material.

Keywords: abrasive jet polishing, nano and micro composites Al-TiC, hardness improvement, $\mathrm{SiO}_{2}$ Kulcsszavak: csiszolófúvós polírozás, Al-TiC nano és mikro kompozitok, keménység növel, $\mathrm{SiO}_{2}$
\end{abstract}

\section{Introduction}

The surface finish of Al-TiC components plays an important role in the mechanical response and wear resistance. Therefore, the surface treatment is a primordial process to achieve certain qualities that are not available from the primary manufacturing processes. One of the effective surface treatment processes is the polishing process using abrasive jet of particles. The effect of polishing techniques and penning on surface roughness and hardness are widely studies on composites [1]. Abrasive jet machining (AJM) is a process that does not include a physical contact between the tool and work piece so there are no thermal stresses and shocks developed. AJM can be used for many processes such as cutting, cleaning, polishing, etching, drilling and finishing operations. The effects of polishing techniques on surface roughness and micro hardness of resin composites are desirable in order to reduce the number of clinic sessions and bringing more comfort and satisfaction to the patient in dental application [2-4]. In addition, the air abrasion is commonly used on surface treatment for porcelain veneers [5]. The effect of different air-abrasion particles on metal-ceramic bond strength is widely analyzed in the work of Tolga Kulunk et al. [6]. Other studies using abrasive water jet polishing were conducted to improve the fatigue strength of metals [7, 8]. F. Boud et al. [9] studied the impact of plain water jet machining on the surface integrity of aluminum 7475 . Others focused on penning treatment such as Kyun-Taek Cho et al. [10] who worked on surface hardening of aluminum alloy by soft-shot polishing treatment with $\mathrm{Zn}$ based ball. In this work, a nano and micro composites of $\mathrm{Al}-\mathrm{TiC}$ are chosen as testing materials. Several previous works have been done in the synthesis of $\mathrm{Al}-\mathrm{TiC}$ composites $[11,12]$. In an attempt to improve the $\mathrm{Al}-\mathrm{TiC}$ composites surfaces hardness with different $\mathrm{TiC}$ sizes and ratios a high efficient and low-cost AJP machine is designed to conduct the proposed testing.

\section{Experimental procedures}

Aluminum (Al) was used as matrix material whereas $\mathrm{TiC}$ particles with different sizes and ratios (300-500 nm and 100$200 \mu \mathrm{m}),(5,10,15,20$ and $25 \mathrm{wt}$. \%) were used as reinforcement in the Al-TiC composites. Melting of $\mathrm{Al}$ was carried out using a resistance furnace operating at $850^{\circ} \mathrm{C}$. The reinforcements were then added gradually for 10 minutes to the molten aluminum with different weight ratios (5, 10, 15, 20 and 25) wt.\% of TiC. Mixtures were stirred for 10 minutes after the additions of TiC. The stirrer rod was operated at $450 \mathrm{rpm}$ to ensure a good distribution and homogeneity of the nano and micro $\mathrm{TiC}$ powder in the molten $\mathrm{Al}$ matrix. With $10^{\circ} \mathrm{C} / \mathrm{min}$ heating rate the furnace, the temperature was held at $850^{\circ} \mathrm{C}$ to ensure high fluidity of Al. After the Al-TiC became homogenous, the liquefied $\mathrm{Al}-\mathrm{TiC}$ was poured in to previously prepared sand mould. However, at a temperature of $700^{\circ} \mathrm{C}$ the molten became in a semi-solid state, where the slurry cannot be poured into the mold because at this stage, its viscosity is high and the fluidity is greatly low. Therefore, before pouring the slurry into the mold, it was necessary to re-melt it to a molten condition, and re-stir before pouring [13]. The abrasive jet machine (AJM) is utilized in the unconventional machining process of material removal from a work piece by the application of a high speed stream of abrasive particles carried in the air medium from a nozzle as shown in Fig. 1.

The AJM is used to cut hard and brittle materials where a three-axis CNC machine is utilized for material removal process. The machines are designed and selected through appropriately to o the tasks. To design and construct the AJM components several factors have to be considered: compressible flow law, carrier gas, flow rate, vibration level, nozzle size, stand-off effects, material removable rate estimation, etc. The 
selection of parts, the assembly process, the fabrication and the test of the machine performance were carried out. The AJM was designed and constructed to perform a CNC engraving, cutting and drilling as shown in Fig. 2.

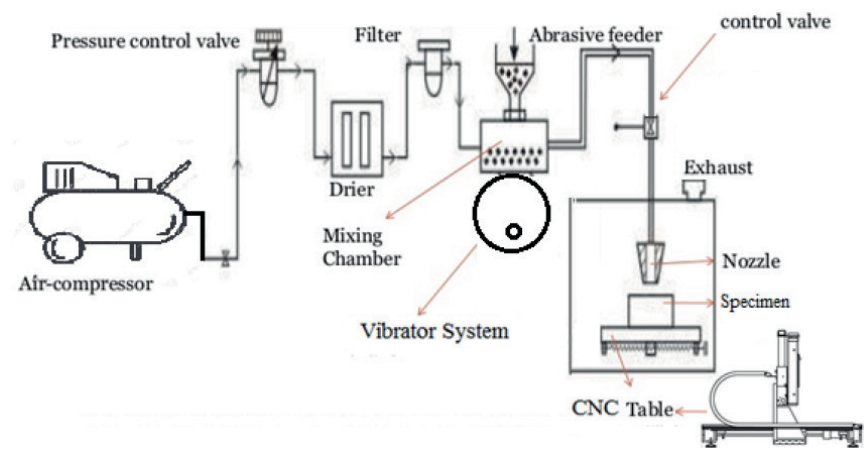

Fig. 1 Schematic representation of the AJM

1. ábra AJM sematikus ábrázolása

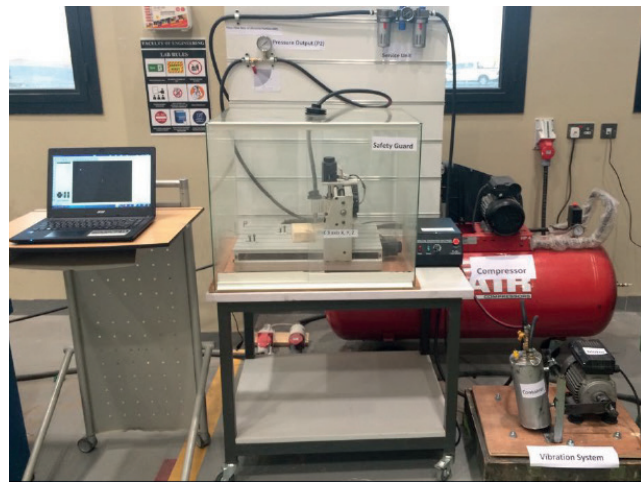

(a)

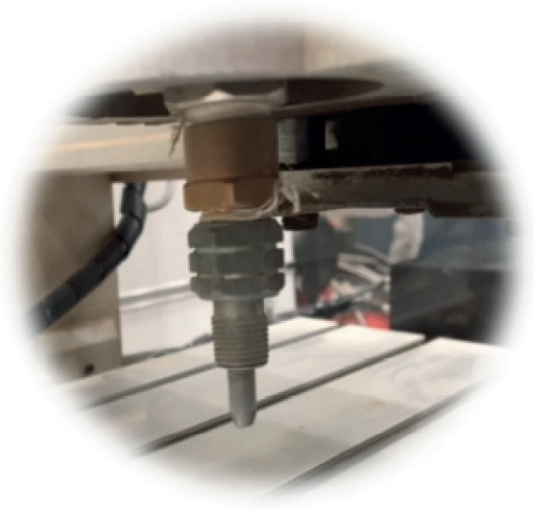

(b)

Fig. 2 The abrasive jet machine (AJM) (a), the nozzle ( $b$ )

2. ábra AJM (a), fúvóka (b)

The AJP was designed with abrasive Silica sand $\left(\mathrm{SiO}_{2}\right)$ and used with a $90^{\circ}$ impact angle and average gas pressure of around 5 bar with $2 \mathrm{~mm}$ nozzle diameter and a standoff height of 10 $\mathrm{mm}$. The mass flow rate of $\mathrm{SiO}_{2}$ was set to $1.2 \mathrm{gram} / \mathrm{s}$. Total polishing time was 10 seconds. Control of the nozzle position and the blasting time on the top surface were controlled by a CNC table. Hardness test evaluation was carried out through the Brinell test machine WP 300 from GANT Company. Brinell hardness test carried out at $9.8 \mathrm{KN}$ for 30 seconds. The test was used to investigate the influence of sizes and weight fraction of $\mathrm{TiC}$ on the matrix hardness. A total of five samples were taken for each ratio of the $\mathrm{Al}-\mathrm{TiC}$ to obtain the average hardness value for an accurate result. The concept of hardness improvement by abrasive jet polishing of $\mathrm{SiO}_{2}$ particles is represented in Fig. 3. The Silica sand $\mathrm{SiO}_{2}$ particles are characterized by a large number of irregular angular surface features and have a relatively high hardness (Mohs Hardness 6-7).

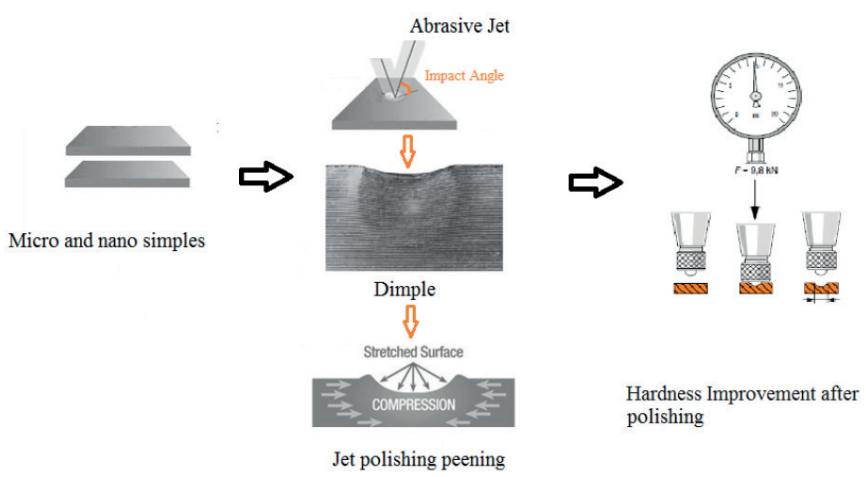

Fig. 3 The concept of hardness improvement by abrasive jet polishing of $\mathrm{SiO}_{2}$ 3. ábra A keménység növelésének koncepciója $\mathrm{SiO}_{2}$ csiszolófúvós polírozásával

In order to evaluate the efficiency of the abrasive polishing machine, a primary experiment was carried out on four known specimens delivered from GANT Company under standard references as shown in Table 1. The polishing test was performed using aluminum alloy EN AW-6082 (called in ISO: Al Si1MgMn), copper CW004A (designation for the $99.9 \%$ pure copper ), Brass CW614N with $37-45 \%$ Zinc, steel alloy S235 - IAC-C with maxi C\% of 0.22 and Mn \% of 1.6.

Based to the experimental results grouped in Table 1, it is observed that the increasing of the hardness of the aluminum alloy is about $51 \%$, for the copper alloy is $73 \%$, for brass is $53 \%$ and for steel is $29 \%$. The improvement of surface hardness was significant, which confirm the effectiveness of the present jet polishing process on the material surface finishing.

\begin{tabular}{|c|c|c|c|}
\hline Material & $\begin{array}{l}\text { Brinell } \\
\text { Hardness } \\
\text { before } \\
\text { polishing }\end{array}$ & $\begin{array}{c}\text { Brinell Hardness } \\
\text { after polishing } \\
t^{*}=10 \text { s } d^{*}=10 \mathrm{~mm} \\
\text { Polishing at } \mathrm{MP}=1.2 \\
\text { gram } / \mathrm{s}\end{array}$ & $\begin{array}{l}\text { Percentage } \\
\text { of hardness } \\
\text { improvement } \\
\text { MP* }=1.2 \\
\text { gram } / \mathrm{s}\end{array}$ \\
\hline $\begin{array}{l}\text { Aluminum } \\
\quad \text { Alloy } \\
\text { EN AW-6082 }\end{array}$ & $67 \mathrm{HB}$ & $101 \mathrm{HB}$ & $51 \%$ \\
\hline $\begin{array}{c}\text { Copper Alloy } \\
\text { CW004A }\end{array}$ & $55 \mathrm{HB}$ & $95 \mathrm{HB}$ & $73 \%$ \\
\hline $\begin{array}{c}\text { Brass } \\
\text { CW614N }\end{array}$ & $90 \mathrm{HB}$ & $138 \mathrm{HB}$ & $53 \%$ \\
\hline $\begin{array}{c}\text { Steel } \\
\text { S235-IAC-C }\end{array}$ & $130 \mathrm{HB}$ & $168 \mathrm{HB}$ & $29 \%$ \\
\hline \multicolumn{4}{|c|}{$\begin{array}{l}{ }^{*} t(\mathrm{~s}): \text { Time of polishing. } \\
{ }^{*} \mathrm{~d}(\mathrm{~mm}): \text { Standoff distance between nozzle and top surface of the workpiece. } \\
{ }^{*} \mathrm{MP}(\mathrm{gram} / \mathrm{s}): \text { Mass flow rate of abrasive particle of } \mathrm{SiO}_{2}\end{array}$} \\
\hline
\end{tabular}

\section{Results and discussion}

\subsection{Hardness results before polishing}

In this part, hardness test was conducted to investigate the influence of sizes and weight fraction of $\mathrm{TiC}$ on the matrix 
hardness. A total of five samples were taken for each ratio of Al$\mathrm{TiC}$ to obtain the average hardness value for an accurate result. The hardness values of the micro and nano composites depend on the amount of particles, sizes, and uniformity distribution of $\mathrm{TiC}$ particles in the $\mathrm{Al}$ matrix as shown in Fig. 4.

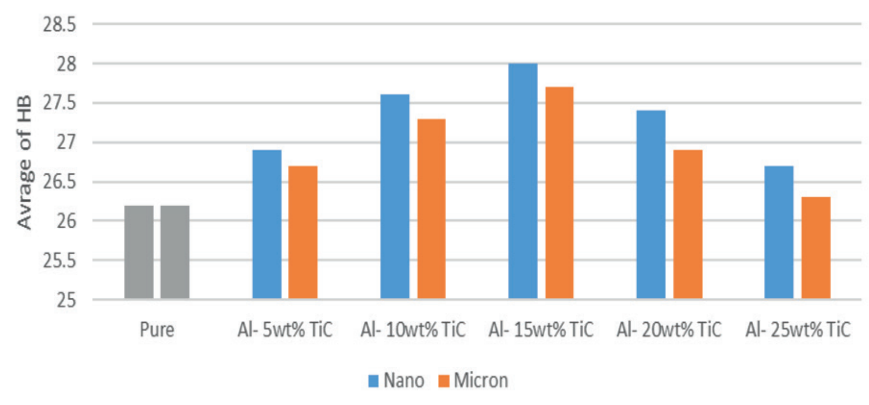

Fig. 4 Comparison between average HB for nano and micro

4. ábra Átlagos Brinell-keménység összehasonlítása nano-és mikro kompozitokon

It is observed from the results of hardness in Fig. 4 that all reinforced specimens have a higher hardness than that of the matrix material. In general, the hardness increases with increasing the hard particles (TiC). The hardness for specimens with $20 \mathrm{wt} \%$ and $25 \mathrm{wt} \% \mathrm{TiC}$ decreases due to the agglomeration of $\mathrm{TiC}$ particles. For these samples, the highest hardness measured is at $15 \mathrm{wt} \% \mathrm{Nano} \mathrm{TiC}$ at $28 \mathrm{HB}$ while the minimum hardness is at $0 \mathrm{wt} \%$, and that proves that the aluminum reinforced with $\mathrm{TiC}$ improves the hardness. Moreover, it was observed based on Fig. 4 that the nano-particles of TiC gives a little higher hardness for the composite Al-TiC compared with micro particles. The decrease of hardness at $20 \mathrm{wt} \%$ and 25 $\mathrm{wt} \%$ of $\mathrm{TiC}$ is due to the effects of grain boundary.

The presented results had been observed in several investigations, which indicated the decrease of hardness below a critical grain size [17], [18] and [19]. Both experiments and simulations in [20], [21] and [22] have also shown that the strength/hardness decreases with further grain refinement below the critical value. This indicates the occurrence of a shift in the dominated deformation mechanisms from dislocationmediated plasticity to grain-boundary-associated plasticity such as grain-boundary sliding, grain-boundary diffusion and grain rotation. Due to the small size of powder (especially in nano powder) a change is evident in hardness value for each specimen. If a particle is dispersed in the composite, a better value for hardness would be obtained. The agglomeration that occurs affects the mechanical behavior of the specimen. This is due to the powder collected at one portion of the specimen that causes a soft and porous surface.

\subsection{Hardness improvement after polishing of the composite Al-TiC}

All specimens were tested for Brinell hardness before the polishing. The outer surfaces of the workpieces were machined using an abrasive jet at a standoff of $10 \mathrm{~mm}$ and mass flow rate of abrasive particles of 1.2 gram/s. Then, the Brinell hardness test was repeated again on the same specimens. The degree of surface roughness was changed and the hardness as well. The amelioration of the hardness of the nano and micro composite $\mathrm{Al}-\mathrm{TiC}$ simples at different ratios of $\mathrm{TiC}$ are regrouped in Table 2.
The percentage rates of hardness improvement in specimens were calculated through five experimental tests on each specimen. The average is presented in Table 2 for microcomposite and nano-composite with different ratios of $\mathrm{TiC}$. By comparing the hardness before and after polishing it is clearly noticed that the increasing of hardness is about $7 \%$ to $15 \%$ for nanocomposites and about $6 \%$ to $11 \%$ for micro-composites due to the impact

of $\mathrm{SiO}_{2}$ particles by abrasive jet polishing. This process produces tensile stresses in the surface because the surface is trying to become plastically larger.

As a reaction to the polishing or peening treatment a compressive unused stress is formed in the surface layer. These compressive unused stresses have to be balanced by unused tensile stresses in the entirely elastically deformed component interior.

\begin{tabular}{|c|c|c|c|}
\hline $\begin{array}{c}\text { Material } \\
\text { specimen } \\
\text { micro } \\
\text { composites }\end{array}$ & $\begin{array}{l}\text { Before } \\
\text { polishing } \\
\text { (HB) }\end{array}$ & $\begin{array}{c}\text { After } \\
\text { polishing } \\
\text { (HB) }\end{array}$ & $\begin{array}{c}\text { Percentage of } \\
\text { hardness } \\
\text { improvement }\end{array}$ \\
\hline Pure Al & 26.2 & 28 & $7 \%$ \\
\hline Al- 5wt\% TiC & 26.7 & 28.7 & $7 \%$ \\
\hline Al- 10wt\% TiC & 27.3 & 29 & $6 \%$ \\
\hline Al- 15wt\% TiC & 27.7 & 30.7 & $11 \%$ \\
\hline Al-20wt\% TiC & 26.9 & 29 & $8 \%$ \\
\hline Al- 25wt\% TiC & 26.3 & 28.5 & $8 \%$ \\
\hline $\begin{array}{c}\text { Material } \\
\text { specimen } \\
\text { nano } \\
\text { composites }\end{array}$ & $\begin{array}{c}\text { Before } \\
\text { polishing } \\
\text { (HB) }\end{array}$ & $\begin{array}{c}\text { After } \\
\text { polishing } \\
\text { (HB) }\end{array}$ & $\begin{array}{l}\text { Percentage } \\
\text { of hardness } \\
\text { improvement }\end{array}$ \\
\hline Pure Al & 26.2 & 28.4 & $8 \%$ \\
\hline Al- 5wt\% TiC & 26.9 & 28.8 & $7 \%$ \\
\hline Al- 10wt\% TiC & 27.6 & 30.5 & $11 \%$ \\
\hline Al- 15wt\% TiC & 28 & 32.3 & $15 \%$ \\
\hline Al-20wt $\%$ TiC & 27.4 & 31 & $13 \%$ \\
\hline Al- 25wt\% TiC & 26.7 & 29 & $9 \%$ \\
\hline
\end{tabular}

Table 2 Hardness improvement for micro, and nano polishing Al- TiC composites 2. táblázat Az nano-és mikro polírozott Al-TiC kompozitok keménységének növekedése

The position of the maximum of compressive residual stresses depends on several parameters such as: the compressible flow law, carrier gas, flow rate, vibration level, nozzle size, stand-off effects, material removable rate estimation, etc. With increasing the shot peening time, deeper surface layers are plastically deformed, until a saturation is reached, which depends on the energy of the impact shot. The surface shows an increased dislocation density and roughness after shot polishing as in Figs. 5(b) and 6(b). This increase in the dislocation density leads to an increase in the material strength of the surface. This hardening of the polishing Al-TiC composite surfaces have been easily proven by Brinell hardness as shown in Table 2. In addition, it is noticed that the hardness decreases after 
reaching $15 \mathrm{wt} \%$ of $\mathrm{TiC}$ in the aluminum matrix due to the high content of $\mathrm{TiC}$ in the $\mathrm{Al}$ matrix, which is very sensitive to the agglomeration of $\mathrm{TiC}$.

\subsection{Microstructure Image Analyses}

The micrographs shown in Figs. 5(a) and 6(a) clearly display the distribution of the $\mathrm{TiC}$ particles (dark areas) in the $\mathrm{Al}$ matrix (bright areas). As shown in Figs. 5(a) and 6(a), the small particles are distributed homogenously among the big particles (agglomeration of many small particles together). It should be noted that the particle sizes of the small particles are uniformly distributed. However, some pores can be observed. The formation of pores is mainly due to the non-uniformity of the initial TiC particles. Moreover, it is clear from Figs. 5(a) and 6(a) that the reinforcement particles of the composites are embedded in the aluminum matrix. A small agglomeration of $\mathrm{TiC}$ particles in the aluminum matrix has been noticed, and this is mainly due to the non-homogeneity involved in the mixing process carried out before casting. The size of the $\mathrm{TiC}$ particles in the composites increases as the $\mathrm{TiC}$ content increases.

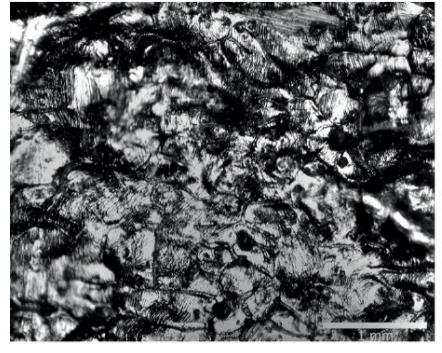

(a)

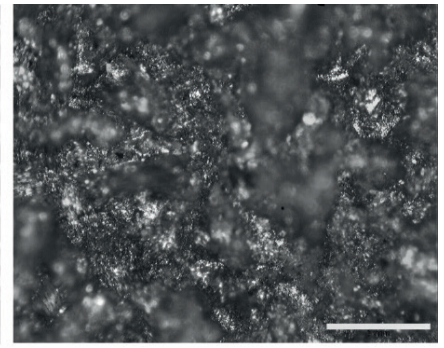

(b)
Fig. 5 Microscopic observation of the nanocomposite $\mathrm{Al} \mathrm{TiC} \mathrm{at} \mathrm{Wt} \mathrm{10 \%}$ (a) before polishing and (b) after polishing

5. ábra Al TiC nanokompozitok mikroszkópos vizsgálata (a) polirozás elött és (b) polirozás után

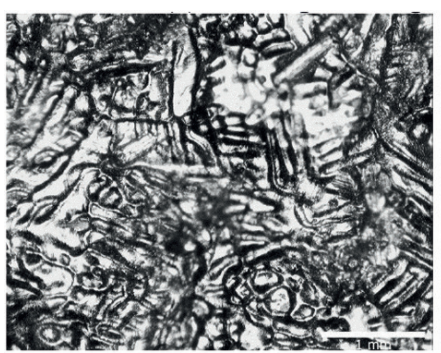

(a)

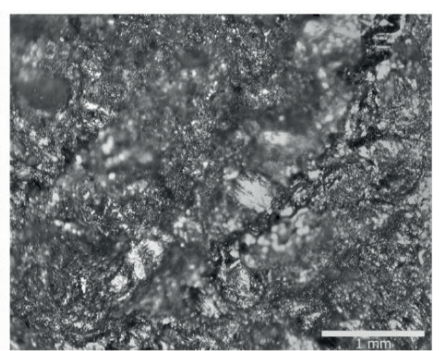

(b)
Fig. 6 Microscopic observation of the microcomposite Al TiC at Wt 10\% before polishing and (b) after polishing

6. ábra Al TiC mikrokompozitok mikroszkópos vizsgálata (a) polírozás elött és (b) polírozás után

The surface shows an increased dislocation density and roughness after shot polishing as in Figs. 5(b) and 6(b). This increase in dislocation density leads to an increase in the porosity and material strength in the surface. The increase in roughness inherited during shot peening must always be considered as negative. At higher magnification overlaps, micro-cracks and areas with an obvious turbulent flow can be found. With the increase in peening time the surface roughness increases as well. A compressive residual stresses can be done to drastically reduce the faster crack propagation rate of the homogeneously deforming surface zone.

\section{Conclusion}

The presented study exposes the improvement of hardness for composites surfaces by Abrasive Jet Polishing (AJP). Composites of $\mathrm{Al}-\mathrm{TiC}$ have been synthesized successfully by stir casting process with different sizes and ratios of $\mathrm{TiC}(300-500 \mathrm{~nm}$, and 100-200 $\mu \mathrm{m})$ and $(5,10,15,20$ and 25 wt.\%) respectively. An AJP by abrasive silica sand $\left(\mathrm{SiO}_{2}\right)$ was used to conduct the experiments. The increases in surface hardness for aluminum alloy, copper alloy, brass, steel were about 51\%, 73\%, 53\%, and 29\%, respectively. Hardness improvement for pure aluminum, Al-microTiC, Al-nanoTiC composites were 7\%, 11\%, and $15 \%$, respectively. From the introduced results, improvements in polished surface workpiece are limited by the $\mathrm{SiO}_{2}$ grainimpact phenomenon and the embedment of $\mathrm{SiO}_{2}$ fragments in the workpiece surface. The surface shows an increased dislocation density and roughness after shot polishing. This increase in dislocation density leads to an increased porosity, material strength in the surface, and reduction the faster crack propagation rate of the homogeneously deforming surface zone. The obtained results on Al-TiC composite demonstrate the importance of superficial hardening of composites by impact of the $\mathrm{SiO}_{2}$ air jet and show that the surface hardness improvement is greatest for the nanocomposites compared with micro-composite and pure matrix material.

\section{References}

[1] Chen, Fengjun - Miao, Xiangliang - Tang, Yu - Yin, Shaohui (2017): A review on recent advances in machining methods based on abrasive jet polishing (AJP), Int. J Adv Manuf Technol 2017,90:785-799. https://doi.org/10.1007/s00170-016-9405-7

[2] Venturini, D. - Cenci, M.S. - Demarco, F.F. - Camacho, G.B. - Powers, J.M (2006): Effect of Polishing Techniques and Time on Surface Roughness, Hardness and Microleakage of Resin Composite Restorations, Operative Dentistry, 2006, 31-1, 11-17. https://doi.org/10.2341/04-155

[3] Kristine Guará Brusaca Almeida ScheibeI - Karoline Guará Brusaca AlmeidaI - Igor Studart Medeiros II - José Ferreira Costa III - Cláudia Maria Coêlho Alves (2009): Effect of different polishing systems on the surface roughness of microhybrid composites, J. Appl. Oral Sci. vol.17 no.1 Bauru Jan./Feb. 2009 http://dx.doi.org/10.1590/S1678-77572009000100005

[4] Michelle Alexandra Chinelatti - Daniela Thomazatti ChimelloI - Renata Pereira Ramos - Regina Guenka Palma-Dibb (2006): Evaluation of the surface hardness of composite resins before and after polishing at different times, J. Appl. Oral Sci. vol.14 no.3 Bauru 2006. doi $-10.1590 /$ S1678-77572006000300008

[5] Aswal, G S - Nair, C K (2015): Effects of various parameters of alumina air abrasion on the mechanical properties of low- fusing feldspathic porcelain laminate material, SADJ 2015, Vol 70 no 4 p150 - p155

[6] Tolga Kulunk - Murat Kurt - C, agrı Ural - S, afak Kulunk - Seniha Baba, (2011): Effect of different air-abrasion particles on metal-ceramic bond strength, Journal of Dental Sciences 2011 6, 140-1460. doi: 10.3109/00016357.2010.536907

[7] D. Arola - A. E. Alade - W. Weber,(2006): Improving Fatigue Strength of Metals Using Abrasive Waterjet Polishing, Machining Science and Technology, 10: 2006, 197-218. https://doi.org/10.1080/10910340600710105

[8] A. Azhari - S Sulaiman - A K Prasada Rao (2016): A review on the application of polishing processes for surface treatment, IOP Conf. Series: Materials Science and Engineering 114,2016 012002. https://doi.org/10.1088/1757-899X/114/1/012002

[9] F. Boud - L. F. Loo - P. K. Kinnell (2014): The Impact of Plain Waterjet Machining on the Surface Integrity of Aluminium 7475, Procedia CIRP 13, 2014,382 - 386. doi: 10.1016/j.procir.2014.04.065 
[10] Kyun Taek Choa - Kyung Song - Sang Ho Oh - Young-Kook Lee - Kyoung Mook Lim - Won Beom Lee (2012): Surface hardening of aluminum alloy by shot polishing treatment with $\mathrm{Zn}$ based ball, Materials Science and Engineering A 543, 2012, 44-49.

https://doi.org/10.1016/j.msea.2012.02.043

[11] Malek Ali - Ali Samer Muhsan - Projjal Basu - Faiz Ahmad1 (2013):Wear resistance of Al-12Si Alloys by Reinforcing TiC and TiN Particles. Journal of Engineering Mechanics (2013) 10.1061/(ASCE)EM.19437889.0000743. doi: 10.1061/(ASCE)EM.1943-7889.0000743

[12] Malek Ali - Samer Falih (2014): Synthesis and Characterization of Aluminum Composites Materials Reinforced with TiC Nano- Particles. Jordan Journal of Mechanical and Industrial Engineering, Volu. 8 No. 5, 2014, 244-250.

[13] Hashim, J. - Looney, L. - Hashmi, M. S. J. (1999): Metal matrix campsites: production by the stir casting method. Journal of Materials Processing Technology 1999, 92-93, 1-7.

[14] Chang, J. - Moon, I. - Choi, C.: Refinement of Cast Microstructure of Hypereutectic Al-Si Alloys Through the Addition of Rare Earth Metals, Journal of Materials Science (1998) 33: 5015. https://doi.org/10.1016/S0924-0136(99)00118-1

[15] Saeed Farahany - Hamidreza Ghandvar - Nur Azmah Nordin - Ali Ourdjini - Mohd Hasbullah Idris (2016): Effect of Primary and Eutectic Mg2Si Crystal Modifications on the Mechanical Properties and Sliding Wear Behaviour of an $\mathrm{Al}-20 \mathrm{Mg} 2 \mathrm{Si}-2 \mathrm{Cu}-\mathrm{xBi}$ Composite, Journal of Materials Science \& Technology (2016), Pages 1083-1097. doi: 10.1016/j.jmst.2016.01.014

[16] M. Emamya - N. Nemati - A. Heidarzadeha (2010): The influence of $\mathrm{Cu}$ rich intermetallic phases on the microstructure, hardness and tensile properties of $\mathrm{Al}-15 \% \mathrm{Mg} 2 \mathrm{Si}$ composite, Materials Science and Engineering: A, Volume 527, Issue 12, 2010, Pages 2998-3004. https://doi.org/10.1016/j.msea.2010.01.063
[17] Yalçın, B. (2009): Effect of Porosity on the Mechanical Properties and WearPerformance of 2\% Copper Reinforced Sintered Steel Used in Shock Absorber Piston Production,J. Mater. Sci. Technol.,2009 Vol.25 No.5.

[18] H. Conrad (2004): Grain-size dependence of the flow stress of $\mathrm{Cu}$ from millimeters to nanometers Metallurgical and Materials Transactions A, 35, 2004, pp. 2681-2695. https://doi.org/10.1007/s11661-004-0214-5

[19] C. Schuh - T. Nieh - T. Yamasaki (2002): Hall-Petch breakdown manifested in abrasive wear resistance of nanocrystalline nickel, Volume 46, Issue 10, 24 May 2002, Pages 735-740.

https://doi.org/10.1016/S1359-6462(02)00062-3

[20] Hao Yin - Liu Pan - Qingping Sun (2017): Grain Size Effects on Wear Resistance of Nanocrystalline NiTi Shape Memory Alloy, 2017 Advances in Shape Memory Materials: In Commemoration of the Retirement of Professor Hisaaki Tobushi, vol - 73. doi: 10.1007/978-3-319-53306-3_16

[21] X. Li - Y. Wei - L. Lu - K. Lu - H. Gao (2010): Dislocation nucleation governed softening and maximum strength in nano-twinned metals Nature, 464,2010 , pp. 877-880. doi: 10.1038/nature08929.

[22] D. Wolf - V. Yamakov - S. Phillpot - A. Mukherjee - H. Gleiter (2005): Deformation of nanocrystalline materials by molecular-dynamics simulation: relationship to experiments? Acta Materialia, 53, 2005, pp. 1-40. https://doi.org/10.1016/j.actamat.2004.08.045

$\underline{\text { Ref.: }}$

Gherissi, Abderraouf - Ali, Malik: Superficial hardening improvement of nano and micro composite $\mathrm{Al} \mathrm{TiC}$

Építőanyag - Journal of Silicate Based and Composite Materials, Vol. 72, No. 1 (2020), 25-29. p.

https://doi.org/10.14382/epitoanyag-jsbcm.2020.5

\title{
342 Assembly 1 (A) IAAM \\ European Composite Materials Congress
}

\author{
Biosensors and Bioelectronic Materials Symposium
}

Graphene and 2D Materials Conference

\section{9 - 11 June 2020 | Stockholm, Sweden}

Venue: M/S Mariella, Viking Line Cruise Ship

Stockholm (Sweden) - Helsinki (Finland) - Stockholm (Sweden)

www.advancedmaterialscongress.org/cmc20

The multi-inter-trans-disciplinary Research, Innovations and Technology 